\title{
Encrucijada de descolonizaciones
}

\author{
Por Clément Akassi Animan ${ }^{1}$ \\ Howard University (EE.UU)
}

Nascimento Dos Santos, Daiana. (2015). El océano de fronteras invisibles: relecturas históricas sobre (¿el fin? de) la esclavitud en la novela contemporánea. Madrid: Editorial Verbum, 228p.

El océano de fronteras invisibles de Daiana Nascimento dos Santos no es un libro que viene a colocarse entre nuestras manos y ante nuestros ojos como un libro más sobre África y la diáspora africana. Es más bien una encrucijada de retos y de descolonizaciones en la que precisamente radica la originalidad del libro. El reto lingüistico es uno de los más llamativos. Mediante una aproximación crítica a sus obras, Nascimento dos Santos hace dialogar a los descendientes de africanos en América Latina con los africanos del continente, a través de

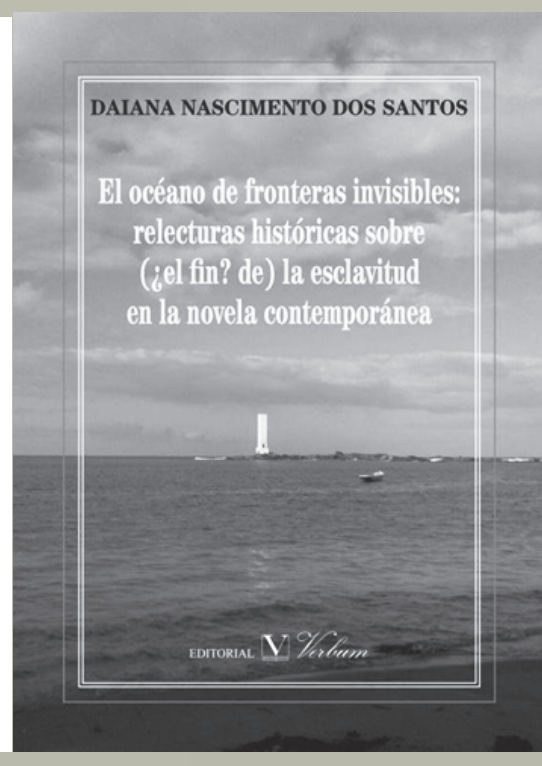
un dominio directo del español y del portugués, dos de las lenguas (pos/coloniales) más habladas por el sujeto esclavizado/colonizado africano. El resultado de tal hazaña es que en el libro de Nascimento dos Santos nos percatamos de que, aunque fueran fragmentadas por la dispersión y ocultas unas de otras, las memorias africanas se desfragmentan reunidas por el muntu y/o por la historia de la esclavitud, y por su consustancial avatar cimarrón que es la resistencia.

Otro reto que le da al libro su aura innovadora es su particular planteamiento crítico que abre nuevas perspectivas dentro del presupuesto teórico de la Nueva Novela Histórica. En efecto, en El océano... no se trata del planteamiento clasista (de clases sociales) e histórico que propone la teoría estructuralista de la Novela Histórica. El libro tampoco trata de acercarse a las producciones literarias estudiadas a partir de la sola indagación en la ficcionalización de los

\footnotetext{
${ }^{1}$ Ph.D. in Spanish w/concentration: in Afro-Caribbean/Afro-Hispanic Studies. e-mail: cakassi@howard.edu
} 
personajes históricos, una de las matrices estructurantes de la Nueva Novela Histórica. El complejo proceso de análisis propuesto por Nascimento dos Santos rebasa más bien las aporías/limitaciones de los designios mimético-estructuralistas e historicistas de la Nueva/ Novela Histórica y saca a luz algunas tensiones histórico-raciales entre el sujeto esclavizador/colonizador y el sujeto esclavizado/ colonizado africano. De modo que en el corpus de El océano..., es decir, en A gloriosa familia (Pepetela, 1997), El reino de este mundo (Alejo Carpentier, 1949), Changó el gran putas (Zapata Olivella, 1983) y Um defeito de cor (Gonçalves, 2006), se denuncia la colonialidad (esclavización y colonialismo inmutables) del discurso sobre las historias nacionales o narraciones de las naciones. En estas obras y bajo la pertinente pluma de Nascimento dos Santos, la producción literaria se vuelve el espacio donde las voces silenciadas en el espacio público vienen a expresarse y reivindicarse. La historia ya no la cuenta solamente el vencedor/esclavizador/colonizador. La narra también el esclavizado-mudo (fuerte metáfora usada en $A$ gloriosa). En este contexto, las intensas y extensas páginas de Changó (más de 500) y de Um defeito (casi 1000) aparecen como un desahogo, un afán de disemiNación (diseminar en la nación) de culturas e historias milenarias africanas opresas, desprestigiadas, ocultas por siglos.

Además de los retos linguísticos y críticos, El océano... se lee también como una encrucijada de descolonizaciones, empezando por la descolonización del imaginario, que es la matriz de todas las demás. Primero, está la descolonización del imaginario en cuanto a las historiografías nacionales y (pos)coloniales. Pues (y para poner uno de los casos), en los intersticios del análisis de Um defeito, surge a toda luz la idea de que el libro no se escribe sólo para transcribir datos históricos encarnados por peculiar(es) personaje(s), sino que se inscribe también en el contexto de las tensiones ideológicas generadas por el discurso sobre la democracia racial en Brasil planteada como imperativo categórico por Gilberto Freyre, en su libro Casa Grande \& Senzala (1933). En otros términos, si Um defeito se escribe más de un siglo después de la abolición de la esclavitud y después de casi tres cuartos de siglo desde la publicación de Casa Grande \& Senzala es porque en Brasil el defecto del color (negro) sigue siendo un problema que no se puede obviar bajo pretexto de democracia racial. En este mismo nivel paradigmático, se sitúa el análisis hecho de El reino en el ensayo de Nascimento dos Santos. Publicado en un contexto internacional de fin de guerra mundial (la segunda) y de contexto cubano de dictatura acérrima y apegada a Estados Unidos, El reino llega a representar las creencias y valores africanos como el nuevo sentido del mundo, o mejor dicho, el nuevo reino de un mundo habitable. Por lo menos, de un mundo de 
creencias que liberan -desde aquella liberación haitiana nacida en la ceremonia del Bois Caïman, hasta la virtud de no haber sido autores de dos guerras mundiales-. ¿No yacería ahí, en El reino, en el narrar de Ti Noel, el contradiscurso africano para con el "siglo de las luces" occidental, esclavizador y colonizador?

Luego, se vislumbra en El océano... la descolonización del imaginario respecto a la epistemología. En efecto, a lo largo de la lectura del libro, no se nos escapa que si Ti Noel en El reino y la propia novela Changó se valen de los mitos, de las epopeyas y leyendas africanas para construirse, es porque se urge la reivindicación de un discurso propio a través de unas tradiciones orales prohíbidas, en nombre de la subyugadora "civilización" de la escritura. En última instancia, por este camino parece ir la propuesta central, ideológica y ética del libro de Daiana Nascimento dos Santos: que para recobrar las memorias fragmentadas en el océano habrá que recurrir también a la memoria viva y oral de África para descolonizar los imaginarios, y por ende, la crítica y la episteme. 